\title{
Increased Cytotoxicity of Vanadium to CHO-K1 Cells in the Presence of Inorganic Selenium
}

\author{
Iwona Zwolak ${ }^{1}$
}

Received: 12 February 2015/ Accepted: 15 July 2015/Published online: 23 July 2015

(c) The Author(s) 2015. This article is published with open access at Springerlink.com

\begin{abstract}
The effect of selenium applied as sodium selenite $\left(\mathrm{Na}_{2} \mathrm{SeO}_{3}\right)$ on the cytotoxicity of vanadyl sulphate $\left(\mathrm{VOSO}_{4}\right)$ was examined using $\mathrm{CHO}-\mathrm{K} 1$ cells. From the resazurin-based assay, it appears that $\mathrm{Na}_{2} \mathrm{SeO}_{3}$ at low doses $(0.5$ and $1 \mu \mathrm{M})$ can enhance $100 \mu \mathrm{M} \mathrm{VOSO}_{4}$-induced cell damage. The two-way ANOVA analysis revealed that the increased cell damage was a consequence of a synergistic interaction of $0.5 \mu \mathrm{M} \mathrm{Na}{ }_{2} \mathrm{SeO}_{3}$ with $\mathrm{VOSO}_{4}$ and $1 \mu \mathrm{M}$ $\mathrm{Na}_{2} \mathrm{SeO}_{3}$ with $\mathrm{VOSO}_{4}$. Observations performed with a phase-contrast microscope showed most cells to be rounded upon treatment with $\mathrm{VOSO}_{4}$ alone. In turn, a majority of cells co-treated with $\mathrm{VOSO}_{4}$ and $1 \mu \mathrm{M} \mathrm{Na} \mathrm{NeO}_{3}$ were elongated, and exhibited cytoplasmic vacuolization. These results warn of the potential contribution of inorganic selenium to vanadium-induced toxicity.
\end{abstract}

Keywords Selenium · Vanadium · Interaction · Cytotoxicity $\cdot \mathrm{CHO}-\mathrm{K} 1$ cells

Vanadium $(\mathrm{V})$ is a trace element in human tissues. So far, no essential functions have been identified for $\mathrm{V}$ in higher animals and people. However, due to the wide and growing use of this element in industry, $\mathrm{V}$ is regarded as an occupational/ environmental pollutant (Fortoul et al. 2014). People can be exposed to $\mathrm{V}$ as a result of combustion of fossil fuels (vanadium is a natural component of coal, oil), $\mathrm{VO}_{5}$ manufacturing, processing of V-rich steel alloy, cleaning/repair of oil-fired boilers, or handling of catalysts for chemical

Iwona Zwolak

iglina@kul.lublin.pl

1 Department of Cell Biology, Institute of Environmental Protection, The John Paul II Catholic University of Lublin, Kraśnicka Ave. 102, 20-718 Lublin, Poland production (Fortoul et al. 2014; Zwolak 2014a). Vanadium poisoning of cattle via ingestion of $\mathrm{V}$-polluted grass has been documented in South Africa (McCrindle et al. 2001; Gummow et al. 2006). Also, there are reports describing adverse $\mathrm{V}$ effects on human health associated with occupational/ environmental exposure via inhalation (Ehrlich et al. 2008; Patel et al. 2009; Zwolak 2014a).

Another element studied here, selenium (Se), is a wellknown micronutrient whose both beneficial and toxic attributes raise a lot of interest among researchers (reviewed by Letavayová et al. 2006; Schrauzer 2009; Rayman 2012; Vinceti et al. 2013a, b). Similar to V, Se can also pose a risk as an environmental pollutant. As reviewed by Lemly (2004), some human activities like coal mining and combustion, metal mining, oil industry or agricultural irrigation can contribute to excessive release of Se to the aquatic environment. Waterborne Se easily bioaccumulates in the food chain and thus even a slight increase in the water concentration of this element threatens fish and wildlife (Lemly 2004). Excessive intake of Se from dietary sources was shown to induce deleterious health effects in animals and people (Zwolak and Zaporowska 2012). On the other hand, there are research studies available that have shown that both $\mathrm{V}$ and Se can exert many biological actions with potential pharmacological applications such as insulin-mimetic and osteogenic activity (V), or antitumor effects (V and Se) (Cortizo et al. 2006; Molinuevo et al. 2008; Rayman 2012; Rehder 2012). Notably, both the form of Se, i.e. sodium selenite, and the form of $\mathrm{V}$, vanadyl sulphate, used for the current study are available to the public as dietary supplements either singly or in combination (Clarkson and Rawson 1999; Rayman 2012). In view of these observations, the research experiments presented in this paper on potential interactive effects between Se and V may be of value. 
As recently published, the toxicity of inorganic $\mathrm{V}$ in mammals can be affected in the presence of certain essential elements. For example, magnesium has been found to depress the adverse outcomes of V in rats (Ś cibior et al. 2013, 2014). In turn, another essential element, iron, exacerbated the $\mathrm{V}$-induced cytotoxicity in vitro (Todorich et al. 2011). The interaction between $\mathrm{V}$ and Se, which has been studied here, has been poorly examined. An early in vivo study by Haider et al. (1998) reported that prooxidant effects of $\mathrm{V}$ in rats can be reduced by Se. However, previous work from our laboratory demonstrated that adverse actions caused by sodium metavanadate in mouse 3T3/BALB fibroblasts could not be prevented by $24 \mathrm{~h}$ preor coexposure with sodium selenite (Zwolak and Zaporowska 2009, 2010). Taking into account the dissimilar results between Haider's and our studies, we decided to continue the examination of the $\mathrm{V}-\mathrm{Se}$ interaction. In the present work, we coexposed the $\mathrm{CHO}-\mathrm{K} 1$ cells to vanadyl sulphate $\left(\mathrm{VOSO}_{4}\right)$ and sodium selenite $\left(\mathrm{Na}_{2} \mathrm{SeO}_{3}\right)$ for $48 \mathrm{~h}$ (instead of $24 \mathrm{~h}$ in the previous work) to show that the time of coexposure of $\mathrm{CHO}-\mathrm{K} 1$ cells to vanadium and selenium in the experimental conditions applied in this study may have importance in showing interactive effects of these elements on cell damage.

The biological interaction resulting from a simultaneous exposure of the organism to two (or more) factors is the type of effect that could not be expected from the addition of individual responses to each factor, in contrast to the additive effect, which is the sum of responses to each factor. There can be two types of biological interactions: synergistic, which results in amplification of the additive effect, and antagonistic, when the additive effect is reduced (Dunne 2010). The two-way ANOVA represents a statistical tool that allows detection of the interaction between factors examined (in this paper these are vanadyl and selenite). Notably, this statistical analysis has already enabled researchers to show interactive effects of $\mathrm{V}$ with chromium (Ścibior et al. 2010) and V with magnesium (Ścibior et al. 2013) on oxidative stress markers in rats. By using the same statistics, the present study reveals that Se given as selenite can synergistically potentiate vanadylinduced cell damage in a $\mathrm{CHO}-\mathrm{K} 1$ cell culture model.

\section{Materials and Methods}

Dulbecco's Modified Eagle's Medium (DMEM), foetal bovine serum (FBS), and the antibiotic-antimycotic mixture were purchased from PAA Laboratories Gmbh (Pasching, AT). Resazurin test, sodium selenite $\left(\mathrm{Na}_{2} \mathrm{SeO}_{3}\right)$, and vanadyl sulphate hydrate $\left(\mathrm{VOSO}_{4} \cdot \mathrm{xH}_{2} \mathrm{O}\right)$ were purchased from Sigma-Aldrich (St Louis, MO, USA). Trypsin solution $(0.25 \%)$ was ordered at Biomed, Lublin, PL.
Chinese hamster ovary cells (CHO-K1 line) were a kind gift from the Department of Cell Biology and Electron Microscopy (Institute of Biology, Jan Kochanowski University of Humanities and Sciences in Kielce, PL). The cells were cultivated in DMEM containing $5 \%$ FBS, 100 $\mathrm{U} / \mathrm{mL}$ penicillin, $100 \mu \mathrm{g} / \mathrm{mL}$ streptomycin, and $0.25 \mu \mathrm{g} /$ $\mathrm{mL}$ amphotericin $\mathrm{B}$ in an incubator at $37^{\circ} \mathrm{C}$ and $5 \% \mathrm{CO}_{2}$. The cultures were passaged twice a week.

For the selenite and vanadyl treatment, the CHO-K1 cells $\left(1 \times 10^{5}\right.$ cells $\left./ \mathrm{mL}\right)$ were seeded on 96 -well microplates in DMEM-5 \% FBS and maintained at $37^{\circ} \mathrm{C}$ in $5 \%$ $\mathrm{CO}_{2}$. The cells were allowed to attach for $2 \mathrm{~h}$. Then, the medium was removed and DMEM-1 \% FBS was added. $24 \mathrm{~h}$ after plating, the medium was replaced with fresh DMEM (with $1 \%$ FBS) containing vanadyl sulphate $(100 \mu \mathrm{M})$ and selenite $(0.1,0.5$ or $1 \mu \mathrm{M})$ and the culture was continued for $48 \mathrm{~h}$. The concentrations of vanadyl and selenite were chosen on the basis of our earlier investigations (Zwolak and Zaporowska 2009; Zwolak 2014b). After vanadyl and selenite exposure, the cytotoxicity was assessed using the resazurin test as described below.

The principle of the resazurin assay is based on the reduction of the blue resazurin dye to red resorufin in the presence of mitochondrial enzymes of metabolically active cells (Vega-Avila and Pungsley 2011). The blue dye resazurin absorbs light at a wavelength of $600 \mathrm{~nm}$. The amount of resazurin in the culture medium that has not been converted to resorufin is proportional to the number of injured cells, which is accompanied by an increase in absorbance at $600 \mathrm{~nm}$ when compared to the control. Our earlier studies described this assay as a convenient and reliable method to measure viability of $\mathrm{CHO}-\mathrm{K} 1$ cells after vanadate or vanadyl exposure (Zwolak 2013, 2014b).

For the assay, the treatment medium, which contained vanadyl or/and selenite, was changed to fresh DMEM (without FBS) and $10 \mu \mathrm{l}$ of resazurin was added to each well. The plates were incubated at $37^{\circ} \mathrm{C}$ in humidified atmosphere of $5 \% \mathrm{CO}_{2}$ for $3 \mathrm{~h}$. Then, the absorbance was read at $600 \mathrm{~nm}$ using a microplate spectrophotometer. Five independent experiments were performed with three wells per each treatment condition.

The data from the resazurin assay are presented as a percentage of untreated control cells and they were calculated as follows: $\mathrm{A}_{\text {test }} / \mathrm{A}_{\text {control }} \times 100 \%\left(\mathrm{~A}_{\text {test }}:\right.$ absorbance of cells treated with vanadyl or/and selenite, $A_{\text {control }}$ : absorbance of control cells). In the resazurin assay (colorimetric reading), cytotoxicity (or cell damage) is indicated by an increase in percentage values when compared to the control cells (cells which were not treated with vanadium or/and selenium). For statistical analysis, the absorbance values from five independent experiments were imported to the SPSS program. After the assurance of the normality of distribution, the two-way ANOVA was 
carried out to assess the influence of vanadyl, selenite, and their interaction (vanadyl $\times$ selenite) on the cytotoxicity. When a significant interactive effect between vanadyl and selenite was detected, subsequent calculations were performed in order to indicate the character of the interaction revealed, as described by Ścibior et al. (2012). Accordingly, when the simultaneous treatment of cells with vanadyl and selenite induced a cytotoxic effect that was greater $(\mathrm{V}+\mathrm{Se}$ effect $>\mathrm{V}$ effect $+\mathrm{Se}$ effect $)$ or smaller $(\mathrm{V}+\mathrm{Se}$ effect $<\mathrm{V}$ effect $+\mathrm{Se}$ effect $)$ than the sum of effects induced separately by vanadyl and selenite, the interaction was regarded as synergistic or antagonistic, respectively. One-way ANOVA followed by Dunnett's T3 as a post hoc test was used in order to assess the differences between the means of the treatment groups. $p<0.05$ was considered as significant.

\section{Results and Discussion}

The results of the resazurin assay obtained demonstrated that the 48-h exposure of $\mathrm{CHO}-\mathrm{K} 1$ cells to $100 \mu \mathrm{M}$ vanadyl alone induced significant $(p<0.05$, one-way ANOVA with Dunnett's T3 test) cytotoxicity compared to the control (cells treated with neither vanadyl nor selenite, Fig. 1). Treatment of cells only with selenite at concentrations of

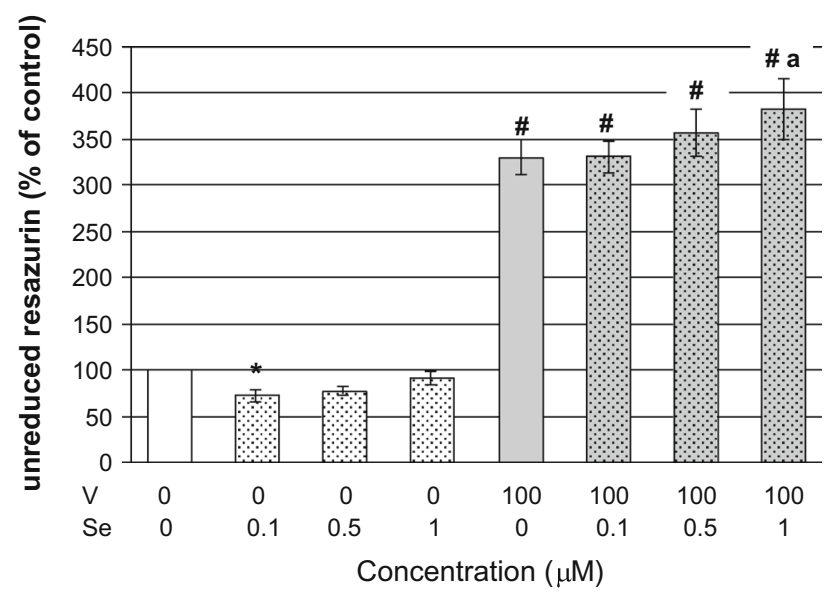

Fig. 1 Cytotoxicity of $\mathrm{V}\left(\mathrm{VOSO}_{4}\right)$ and its combination with $\mathrm{Se}$ $\left(\mathrm{Na}_{2} \mathrm{SeO}_{3}\right)$ to $\mathrm{CHO}-\mathrm{K} 1$ cells as measured with the resazurin assay. The CHO-K1 cells were exposed to $100 \mu \mathrm{M} \mathrm{VOSO}_{4}$ in combination with $\mathrm{Na}_{2} \mathrm{SeO}_{3}(0.1,0.5$ or $1 \mu \mathrm{M})$ for $48 \mathrm{~h}$ and thereafter the cytotoxic effect was assessed with the resazurin test. In this test, the amount of resazurin that was not reduced to resorufin is proportional to the number of injured cells. The absorbance of resazurin in control cells (treated with neither $\mathrm{V}$ nor Se) was taken as $100 \%$. Results are presented as a percentage of control cells and represent mean \pm SEM derived from five independent experiments. Differences between means (ANOVA/Dunnett's T3 test) are indicated by $* p<0.05$ significantly lower than control, ${ }^{*} p<0.001$ significantly higher than control, ${ }^{\mathrm{a}} p<0.05$ significantly higher than $\mathrm{V}$ alone
0.1 and $0.5 \mu \mathrm{M}$ seemed to slightly decrease cell damage compared to the control cultures, and the viability of cells exposed to $1 \mu \mathrm{M}$ selenite was similar to the control. The three above-mentioned concentrations of selenite were regarded as non-cytotoxic. Importantly, the review of literature data revealed that cultured mammalian cells substantially differed in their sensitivity to selenite, as described hereafter. For instance, cultured human neuronal cells showed a viability decrease following exposure to selenite at doses as low as $0.1 \mu \mathrm{M}$ (Maraldi et al. 2011). However, concentrations of selenite comparable to those used in our study were non-toxic to primary rabbit hepatocytes (Müller and Pallauf 2003), human hepatoma (HepG2) cells (Helmy et al. 2000), prostatic (PNT-1) cells (Maraldi et al. 2011), or human HaCaT keratinocytes (Hazane-Puch et al. 2013). Notably, human exposure to inorganic selenium via drinking water at concentrations similar to or much higher than those studied here have been documented in some regions of the world (reviewed by Vinceti et al. 2013a).

As presented in Fig. 1, vanadyl in the combination with 0.5 or $1 \mu \mathrm{M}$ selenite induced stronger cytotoxic responses (by $26 \%$ and $52 \%$ respectively) than vanadyl alone, with the latter increase being statistically significant $(p<0.05$, one-way ANOVA with Dunnett's T3 test). The two-way ANOVA analysis (Table 1) revealed that the stronger cytotoxicity in cells co-treated with selenite and vanadyl was due to a synergistic interaction between vanadyl and $0.5 \mu \mathrm{M}$ selenite $(p=0.034)$ and between vanadyl and $1 \mu \mathrm{M}$ selenite $(p=0.002)$. Additionally, in the case of the combination of vanadyl with $1 \mu \mathrm{M}$ selenite, independent action of $1 \mu \mathrm{M}$ selenite $(p=0.006)$ also contributed to the increase in the vanadyl-induced cytotoxicity in the presence of selenite. On the other hand, as can be seen in Fig. 1, selenite at $0.1 \mu \mathrm{M}$ did not affect vanadyl-induced toxicity. This shows a very fine threshold between the dose of selenite that does not interfere with vanadyl adverse effects $(0.1 \mu \mathrm{M}$ selenite $)$ and the dose that can potentiate them $(0.5 \mu \mathrm{M}$ selenite). This certainly is in line with the notion that $\mathrm{Se}$ is an element with a very narrow safe range of exposure (Vinceti et al. 2013b). It is worth reminding that the detected interactive effects between vanadyl and selenite pertain to mitochondrial functions, since the in vitro assay with resazurin applied here records toxic effects of chemicals on the basis of mitochondrial enzyme activity.

The analysis of cell morphology carried out under the phase-contrast microscope showed that the control $\mathrm{CHO}$ $\mathrm{K} 1$ cell culture (at $72 \mathrm{~h}$ from seeding) developed a dense monolayer of cells with an epithelial-like morphology (Fig. 2a). The $48 \mathrm{~h}$ treatment with either of the selenite concentrations tested did not induce any changes in the appearance of the cells, compared to the untreated control 
Table 1 Results of two-way ANOVA on the effects of $\mathrm{Na}_{2} \mathrm{SeO}_{3}(\mathrm{Se}), \mathrm{VOSO}_{4}(\mathrm{~V})$, and the interactive effects between $\mathrm{Na}_{2} \mathrm{SeO}_{3}$ and $\mathrm{VOSO}_{4}(\mathrm{~V} \times \mathrm{Se})$ on CHO-K1 cell damage measured with a resazurin assay

\begin{tabular}{lll}
\hline Two-way anova analysis & & Character of interaction \\
\hline Main effect of $\mathrm{V}$ & $\mathrm{F}=448.948, p=0.000$ & - \\
Main effect of $\mathrm{Se}(0.1 \mu \mathrm{M})$ & $\mathrm{NS}$ & - \\
Interactive effect of $\mathrm{V} \times \mathrm{Se}(0.1 \mu \mathrm{M})$ & $\mathrm{NS}$ & - \\
Main effect of $\mathrm{V}$ & $\mathrm{F}=728.505, p=0.000$ & - \\
Main effect of $\mathrm{Se}(0.5 \mu \mathrm{M})$ & $\mathrm{NS}$ & - \\
Interactive effect of $\mathrm{V} \times \mathrm{Se}(0.5 \mu \mathrm{M})$ & $\mathrm{F}=4.777, p=0.034$ & Synergistic $^{\mathrm{a}}$ \\
Main effect of $\mathrm{V}$ & $\mathrm{F}=1110.036, p=0.000$ & - \\
Main effect of $\mathrm{Se}(1.0 \mu \mathrm{M})$ & $\mathrm{F}=8.249, p=0.006$ & - \\
Interactive effect of $\mathrm{V} \times \mathrm{Se}(1.0 \mu \mathrm{M})$ & $\mathrm{F}=10.578, p=0.002$ & Synergistic $^{\mathrm{a}}$ \\
\hline
\end{tabular}

$N S$ no significant effect

a The effect of $\mathrm{V}$ in the presence of $\mathrm{Se}(\mathrm{V}+\mathrm{Se}$ effect $)>$ sum of the effects of $\mathrm{V}$ and $\mathrm{Se}$ alone (Se effect $+V$ effect) (synergistic interaction) cells (data not shown). Conversely, as expected, $100 \mu \mathrm{M}$ vanadyl promoted significant changes in the appearance of the cells, compared to the control. In this treatment group, most cells were rounded and some cells were shrunk or spindle shaped (Fig. 2b). Additionally, nuclear chromatin condensation and marginalization was observed in the vanadyl-treated cells. As shown in Fig. 2c, cells exposed simultaneously to vanadyl and $1 \mu \mathrm{M}$ selenite for $48 \mathrm{~h}$ obviously differed in their morphology from the vanadylonly treated cells. Most cells were spread and elongated in shape and exhibited cytoplasmic vacuolization (Fig. 2c). The above-described changes were also observed in cultures treated with vanadyl and $0.5 \mu \mathrm{M}$ selenite, but they were less intense. The morphology of the cells incubated with vanadyl and $0.1 \mu \mathrm{M}$ selenite was comparable to that of the vanadyl-only treated cells (data not shown).

The phenomenon of cytoplasmic vacuolization of cultured cells following exposure to toxic compounds is generally seen as deterioration of cell functioning. These vacuoles may develop from different organelles such as Golgi elements, lysosomes, or mitochondria. Eventually, if the cytoplasmic vacuolization proceeds, it leads to destruction of cellular structures and cell death (Henics and Wheatley 1999). Summing up, the vacuolization of cells which were concomitantly treated with vanadyl and $1 \mu \mathrm{M}$ selenite probably indicates an increase in cell damage in comparison with cells treated only with vanadyl, which would be in good agreement with the results obtained in the cytotoxicity assay. Still however, further microscopic analysis based on other methods is required to examine in more detail the apparent morphological differences between cells treated only with vanadyl and cells co-treated with vanadyl and $1 \mu \mathrm{M}$ selenite.

The literature data on interaction between Se and V are sparse. The only study available demonstrated that Se in the form of $\mathrm{SeO}_{2}$ exhibited protective effects against metavanadate-induced neurotoxicity in rats (Haider et al.
1998), which is in sharp contrast with the current report. Probably, the design of experiments involving the use of specific research models or the kind of cells exposed may be attributed to the discrepancy between the results. Still however, the inconstancies between Haider's et al. (1998) and our data show that the potential beneficial properties of inorganic Se during V-induced intoxication should be treated with caution. Some support for the current results comes from our earlier in vitro investigations in which metavanadate-induced cytotoxicity in mouse BALB/3T3 fibroblasts was not changed after 24-h co-treatment with $0.5 \mu \mathrm{M}$ selenite (Zwolak and Zaporowska 2009). Similarly, under current experimental conditions, the 24-h co-exposure to vanadyl and $0.1-1 \mu \mathrm{M}$ selenite did not modify the $\mathrm{V}$-induced cell damage as shown by the resazurin assay and phase-contrast observations (data not shown). This however was not the case after the $48 \mathrm{~h}$ co-treatment, where a significant synergistic effect of the two tested doses of selenite $(0.5$ and $1 \mu \mathrm{M})$ on V-induced cell damage could be noticed. Hence, the time of co-exposure of cells to $\mathrm{V}$ and Se plays a critical role in demonstrating the interactive effects between the two elements.

So far, a number of human and animal/cell culture studies have provided evidence that $\mathrm{Se}$ (inorganic and organic forms) can be an effective countermeasure against the toxicity induced by other elements such as arsenic (As) or cadmium (Cd) (reviewed by Zwolak and Zaporowska 2012). The suggested mechanism of As and Cd detoxification is Se-dependent sequestration of these elements. Moreover, Se-dependent antioxidant enzymes such as glutathione peroxidase or thioredoxin reductase were also reported to play a significant role in the beneficial actions of Se against As or Cd. However, selenium potential to raise the toxicity of elements has also been documented in the literature. For instance, selenite increased the cytotoxicity of arsenite in primary rat hepatocytes (Styblo and Thomas 2001). In the report mentioned, the suggested 

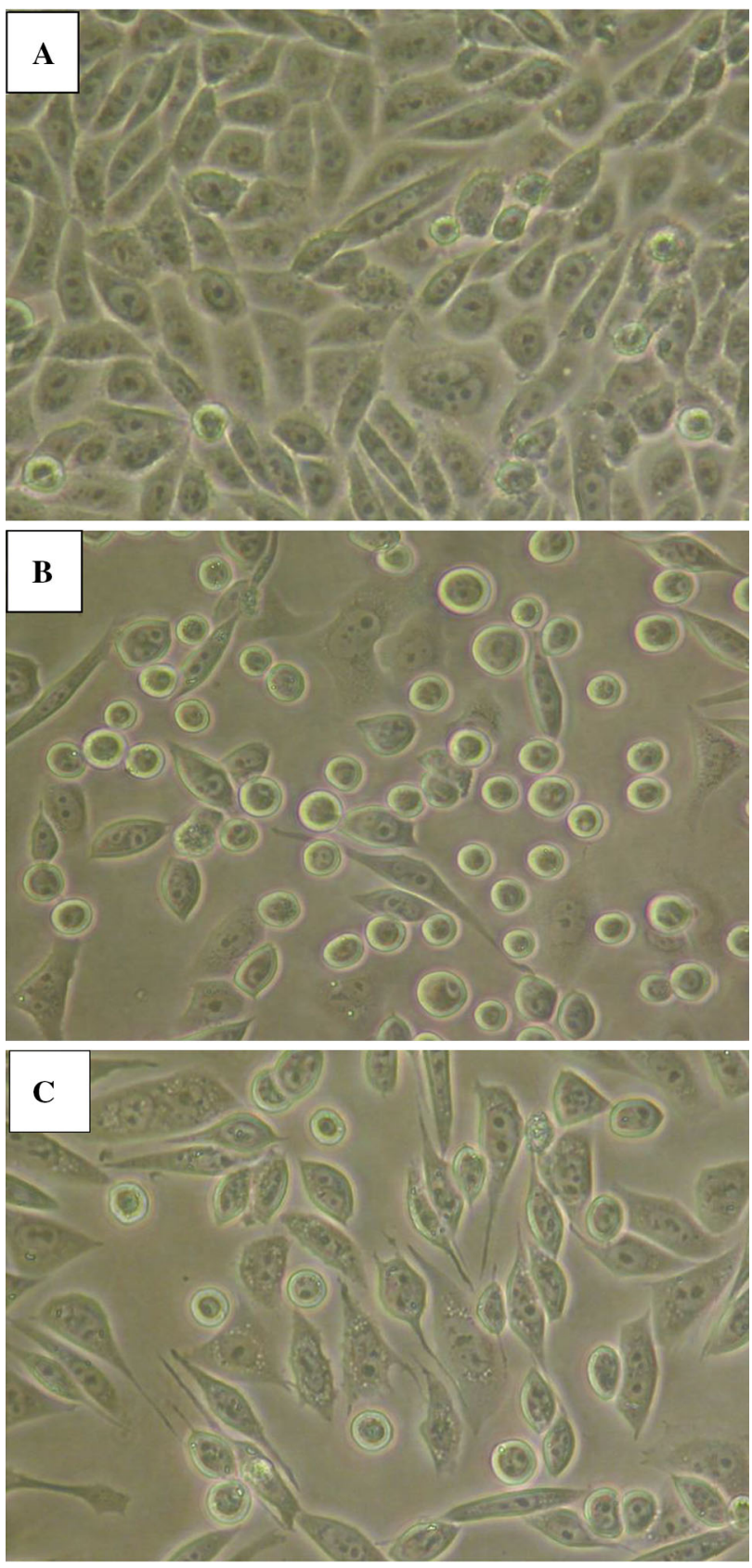

Fig. 2 Morphology of $\mathrm{CHO}-\mathrm{K} 1$ cells under the phase-contrast microscope. a Control cell culture, b cells after 48-h exposure to $100 \mu \mathrm{M} \mathrm{VOSO} 4$, c cells after 48-h exposure to the combination of $100 \mu \mathrm{M} \mathrm{VOSO}_{4}$ with $1 \mu \mathrm{M} \mathrm{Na} \mathrm{SeO}_{3}$

mechanism of Se action was the inhibition of the detoxification pathway leading to increased retention of toxic arsenic forms in the cells examined. Recently, another Se compound, diphenyl diselenide, potentiated methylmercury neurotoxicity in rats (Dalla Corte et al. 2013). To the best of our knowledge, this study is the first to demonstrate that selenite can synergistically enhance the cytotoxicity of vanadyl. The mechanism of this interaction is unknown. Nevertheless, we cannot exclude that it may involve
Se-dependent disturbance of cellular detoxification of vanadium excess. Synergistic toxicity between selenite and vanadyl may also be attributed to increased oxidative stress, as both compounds tested are known for their prooxidant activities (Bay et al. 1997, Yang et al. 2004, Chung et al. 2006).

In summary, by applying advanced statistical methods, this study is the first to show potentiation of vanadyl-induced cytotoxicity in the presence of selenite due to the synergistic interaction between vanadyl and selenite. Further, the increased cytotoxicity was accompanied by the appearance of specific morphological features such as cytoplasmic vacuolization suggesting deterioration of cell functioning. The preliminary data obtained here indicate that inorganic Se can interfere with the cytotoxic effects of $\mathrm{V}$ enhancing them through yet unknown mechanisms.

Acknowledgments The author gratefully thanks Dr. Agnieszka Ścibior for help with the two-way ANOVA analysis.

Open Access This article is distributed under the terms of the Creative Commons Attribution 4.0 International License (http://crea tivecommons.org/licenses/by/4.0/), which permits unrestricted use, distribution, and reproduction in any medium, provided you give appropriate credit to the original author(s) and the source, provide a link to the Creative Commons license, and indicate if changes were made.

\section{References}

Bay BH, Sit KH, Paramanantham R, Chan YG (1997) Hydroxyl free radicals generated by vanadyl (IV) induce cell blebbing in mitotic human Chang liver cells. Biometals 10:119-122

Chung YW, Kim TS, Lee SY, Lee SH, Choi Y, Kim N, Min BM, Jeong DW, Kim IY (2006) Selenite-induced apoptosis of osteoclasts mediated by the mitochondrial pathway. Toxicol Lett 160:143-150

Clarkson PM, Rawson ES (1999) Nutritional supplements to increase muscle mass. Crtit Rev Food Sci Nutr 39:317-328

Cortizo AM, Molinuevo MS, Barrio DA, Bruzzone L (2006) Osteogenic activity of vanadyl (IV)-ascorbate complex: evaluation of its mechanism of action. Int $\mathrm{J}$ Biochem Cell Biol 38:1171-1180

Dalla Corte CL, Wagner C, Sudati JH, Comparsi B, Leite GO, Busanello A, Soares FAA, Aschner M, Rocha JBT (2013) Effects of diphenyl diselenide on methylmercury toxicity in rats. Biomed Res Int 2013:983821

Dunne RP (2010) Synergy or antagonism-interactions between stressors on coral reefs. Coral Reefs 29:145-152

Ehrlich VA, Nersesyan AK, Hoelzl C, Ferk F, Bichler J, Valic E, Schaffer A, Schulte-Hermann R, Fenech M, Wagner KH, Knasmüller S (2008) Inhalative exposure to vanadium pentoxide causes DNA damage in workers: results of a multiple end point study. Env Health Perspect 116:1689-1693

Fortoul TI, Rojas-Lemus M, Rodríguez-Lara V, Gonzalez-Villalva A, Ustarroz-Cano M, Cano-Gutierrez G, Gonzalez-Rendon SE, Montano LF, Altamirano-Lozano M (2014) Overview of environmental and occupational vanadium exposure and associated health outcomes: an article based on a presentation at the 8th international symposium on vanadium chemistry, biological 
chemistry, and toxicology, Washington DC, Augest 15-18, 2012. J Immunotoxicol 11:13-18

Gummow B, Botha CJ, Williams MC (2006) Chronic vanadium poisoning in calves and its treatment with calcium disodium ethylenediaminetetraacetate. Vet Res Commun 30:807-822

Haider SS, Abdel-Gayoum AA, El-Fakhri M, Ghwarsha KM (1998) Effect of selenium on vanadium toxicity in different regions of rat brain. Hum Exp Toxicol 17:23-28

Hazane-Puch F, Champelovier P, Arnaud J, Garrel C, Ballester B, Faure P, Laporte F (2013) Long-term selenium supplementation in HaCaT cells: importance of chemical form for antagonist (protective versus toxic) activities. Biol Trace Elem Res 154:288-298

Helmy MH, Ismail SS, Fayed H, El-Bassiouni EA (2000) Effect of selenium supplementation on the activities of glutathione metabolizing enzymes in human hepatoma HepG2 cell line. Toxicology 144:57-61

Henics T, Wheatley DN (1999) Cytoplasmic vacuolation, adaptation and cell death: a view on new perspectives and features. Biol Cell 91:485-498

Lemly AD (2004) Aquatic selenium pollution is a global environmental safety issue. Ecotoxicol Env Saf 59:44-56

Letavayová L, Vlčková V, Brozmnová J (2006) Selenium: from cancer prevention to DNA damage. Toxicology 227:1-14

Maraldi T, Riccio M, Zambonin L, Vinceti M, De Pol A, Hakim G (2011) Low levels of selenium compounds are selectively toxic for a human neuron cell line through ROS/RNS increase and apoptotic process activation. Neurotoxicology 32:180-187

McCrindle CM, Mokantla E, Duncan N (2001) Peracute vanadium toxicity in cattle grazing near a vanadium mine. J Env Monit 3:580-582

Molinuevo MS, Cortizo AM, Etcheverry SB (2008) Vanadium (IV) complexes inhibit adhesion, migration and colony formation of UMR106 osteosarcoma cells. Cancer Chemother Pharmacol 61:767-773

Müller AS, Pallauf J (2003) Effect of increasing selenite concentrations, vitamin E supplementation and different fetal calf serum content on GPx 1 activity in primary cultured rabbit hepatocytes. J Trace Elem Med Biol 17:183-192

Patel MM, Hoepner L, Garfinkel R, Chillrud S, Reyes A, Quinn JW, Perera F, Miller RL (2009) Ambient metals, elemental carbon, and wheeze and cough in New York City children through 24 months of age. Am J Respir Crit Care Med 180:1107-1113

Rayman MP (2012) Selenium and human health. Lancet 379:1256-1268

Rehder D (2012) The potentiality of vanadium in medicinal applications. Future Med Chem 4:1823-1837

Schrauzer GN (2009) Selenium and selenium-antagonistic elements in nutritional cancer prevention. Crit Rev Biotechnol 29:10-17

Ścibior A, Zaporowska H, Wolińska A, Ostrowski J (2010) Antioxidant enzyme activity and lipid peroxidation in the blood of rats co-treated with vanadium (V5+) and chromium $(\mathrm{Cr} 5+)$. Cell Biol Toxicol 26:509-526

Ścibior A, Adamczyk A, Gołębiowska D, Niedźwiecka I (2012) Effect of 12-week vanadate and magnesium co-administration on chosen haematological parameters as well as on some indices of iron and copper metabolism and biomarkers of oxidative stress in rats. Env Toxicol Pharmacol 34:235-252

Ścibior A, Gołębiowska D, Niedźwiecka I (2013) Magnesium can protect against vanadium-induced lipid peroxidation in the hepatic tissue. Oxid Med Cell Longev 2013:802734

Ścibior A, Adamczyk A, Gołębiowska D, Niedźwiecka I, Fornal E (2014) The influence of combined magnesium and vanadate administration on the level of some elements in selected rat organs: $\mathrm{V}-\mathrm{Mg}$ interactions and the role of iron-essential protein (DMT-1) in the mechanism underlying altered tissues iron level. Metallomics 6:907-920

Styblo M, Thomas DJ (2001) Selenium modifies the metabolism and toxicity of arsenic in primary rat hepatocytes. Toxicol Appl Pharmacol 172:52-61

Todorich B, Olopade JO, Surguladze N, Zhang X, Neely E, Connor JR (2011) The mechanism of vanadium-mediated developmental hypomyelination is related to destruction of oligodendrocyte progenitors through a relationship with ferritin and iron. Neurotox Res 19:361-373

Vega-Avila E, Pungsley MK (2011) An overview of colorimetric assay methods used to assess survival or proliferation of mammalian cells. Proc West Pharmacol Soc 54:10-14

Vinceti M, Crespi CM, Bonvicini F, Malagoli C, Ferrante M, Marmiroli S, Stranges S (2013a) The need for a reassessment of the safe upper limit of selenium in drinking water. Sci Total Env 443:633-642

Vinceti M, Mandrioli J, Borella P, Michalke B, Tsatsakis A, Finkelstein Y (2013b) Selenium neurotoxicity in humans: bridging laboratory and epidemiologic studies. Toxicol Lett 230:295-303

Yang XG, Yang XD, Yuan L, Wang K, Crans DC (2004) The permeability and cytotoxicity of insulin-mimetic vanadium compounds. Pharm Res 21:1026-1033

Zwolak I (2013) Comparison of five different in vitro assays for assessment of sodium metavanadate cytotoxicity in Chinese hamster ovary cells (CHO-K1 line). Toxicol Ind Health. doi:10. $1177 / 0748233713483199$

Zwolak I (2014a) Vanadium carcinogenic, immunotoxic and neurotoxic effects: a review of in vitro studies. Toxicol Mech Methods 24:1-12

Zwolak I (2014b) Comparison of three different cell viability assays for evaluation of vanadyl sulphate cytotoxicity in a Chinese hamster ovary K1 cell line. Toxicol Ind Health. doi:10.1177/ 0748233714544190

Zwolak I, Zaporowska H (2009) Preliminary studies on the effect of zinc and selenium on vanadium-induced cytotoxicity in vitro. Acta Biol Hung 60:55-67

Zwolak I, Zaporowska H (2010) Effects of zinc and selenium pretreatment on vanadium-induced cytotoxicity in vitro. Trace Elem Electrolyte 27:20-28

Zwolak I, Zaporowska H (2012) Selenium interactions and toxicity: a review. Cell Biol Toxicol 28:31-46 